\title{
Author Correction: Design rules for light-emitting electrochemical cells delivering bright luminance at 27.5 percent external quantum efficiency
}

Shi Tang (1), Andreas Sandström (1), Petter Lundberg (1D), Thomas Lanz, Christian Larsen (1), Stephan van Reenen, Martijn Kemerink (1) \& Ludvig Edman (1)

Correction to: Nature Communications https://doi.org/10.1038/s41467-017-01339-0, published online 30 October 2017.

The original version of this Article contained two errors in Fig. 2h, in which the photoluminescence spectra curve of the "PVK:OXD-7" was plotted incorrectly and the figure legends were incorrectly given. The correct version is:

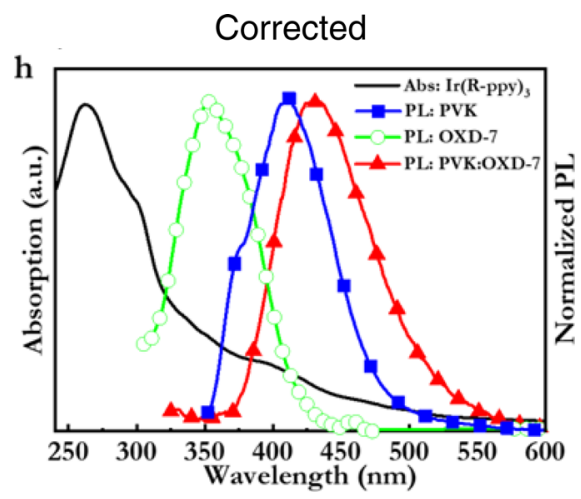

which replaces the previous incorrect version:

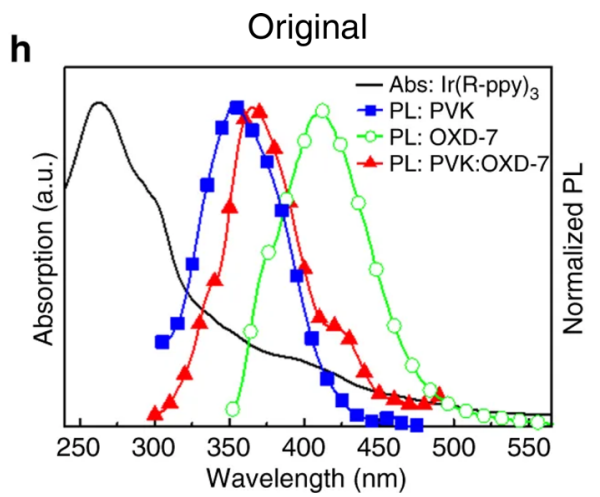

This has now been corrected in both the PDF and HTML versions of the Article. 
(c) Open Access This article is licensed under a Creative Commons Attribution 4.0 International License, which permits use, sharing, adaptation, distribution and reproduction in any medium or format, as long as you give appropriate credit to the original author(s) and the source, provide a link to the Creative Commons license, and indicate if changes were made. The images or other third party material in this article are included in the article's Creative Commons license, unless indicated otherwise in a credit line to the material. If material is not included in the article's Creative Commons license and your intended use is not permitted by statutory regulation or exceeds the permitted use, you will need to obtain permission directly from the copyright holder. To view a copy of this license, visit http://creativecommons.org/licenses/by/4.0/.

(C) The Author(s) 2020 